\title{
Irrigation System Distribution Uniformity Evaluations in the Pajaro Valley, California
}

\author{
Gerardo Spinelli1*, Michael Cahn², Sacha Lozano ${ }^{1}$ and Tom Lockhart ${ }^{2}$ \\ ${ }^{1}$ Resource Conservation District of Santa Cruz County, Capitola, USA \\ ${ }^{2}$ University of California Cooperative Extension Monterey County, Salinas, USA
}

Submission: January 31, 2018; Published: March 12, 2018

"Corresponding author: Gerardo Spinelli, Resource Conservation District of Santa Cruz County, 820 Bay Ave, Capitola, CA 95010, USA, Tel: +15303043738; Email: gerardo.spinelli@gmail.com

\section{Review}

The Resource Conservation District (RCD) of Santa Cruz County and the UC Cooperative Extension of Monterey County performed 25 distribution uniformity (DU) evaluations in the Pajaro Valley between September 2015 and July 2017 following a method developed by Dr. Mike Cahn from the UC Cooperative Extension of Monterey County. The evaluations were performed in collaboration with interested growers and resulted in reports with recommendations to improve the performance of the irrigation system. An estimate of the potential savings, in terms of water and costs, were also included in each evaluation. Funding for the project came from PVWMA and from DWR.

Distribution uniformity is a measure of how evenly water is delivered to the crop and is an indicator of the efficiency of the irrigation system. Less water needs to be applied for a system with a high DU to meet the crop demand than a system with low
DU. By improving DU of the irrigation system water conservation can be achieved at the same time avoiding over-irrigation, runoff and water logging.

Each evaluation consisted of pressure measurements taken at various points across the irrigation system, to evaluate the performance of the pumping station equipment, main and submain lines, valves and pressure regulators. In drip systems lead hose connecting the submain to the drip tape laterals and the drip tape performance were also evaluated. Catch-can experiments were performed in all evaluations, placing cups or bottles under the emitters in drip systems and setting a grid of buckets under sprinkler systems. Other indicators of the irrigation system performance and management were recorded, such as runoff and ponding produced by the irrigation, leaks, row orientation, system flushing, emitter plugging, nozzle wear etc.

Table 1: Summary of the distribution uniformity evaluation performed.

\begin{tabular}{|c|c|c|c|c|c|c|}
\hline $\begin{array}{c}\text { Evaluation } \\
\text { Number }\end{array}$ & Evaluation Date & Farm size & Crop & Area evaluated & $\begin{array}{l}\text { Irrigation } \\
\text { method }\end{array}$ & $\begin{array}{c}\text { Distribution } \\
\text { Uniformity }\end{array}$ \\
\hline & & Acres & & Acres & & \\
\hline 137 & $9 / 23 / 2015$ & 40 & Strawberry & 3.3 & Drip tape & $73 \%$ \\
\hline 138 & $10 / 23 / 2015$ & 20 & Red Beets & 1.8 & Sprinklers & $80 \%$ \\
\hline 139 & $10 / 27 / 2015$ & 45 & Strawberry & 3 & Drip tape & $66 \%$ \\
\hline 140 & $12-02-2015$ & 20 & $\begin{array}{c}\text { Potted } \\
\text { ornamentals }\end{array}$ & 0.6 & Sprinklers & $68 \%$ \\
\hline 141 & $02-12-2016$ & 10.5 & Strawberry & 2.6 & Drip tape & $88 \%$ \\
\hline 142 & $2 / 22 / 2016$ & 50 & $\begin{array}{c}\text { Raspberry \& } \\
\text { Blackberry }\end{array}$ & 2.3 & Drip tape/Hose & $38 \%$ \\
\hline 143 & 03-02-2016 & 62 & Strawberry & 2.8 & Drip tape & $87 \%$ \\
\hline 144 & $2 / 26 / 2016$ & 50 & Strawberry & 3.3 & Drip tape & $84 \%$ \\
\hline 145 & $3 / 26 / 2016$ & 34 & Strawberry & 3.2 & Drip tape & $96 \%$ \\
\hline 146 & $4 / 26 / 2016$ & 34 & $\begin{array}{c}\text { Organic } \\
\text { Blackberry }\end{array}$ & 1.8 & Drip tape & $74 \%$ \\
\hline 147 & 05-06-2016 & 9 & $\begin{array}{c}\text { Organic } \\
\text { Blackberry }\end{array}$ & 3.5 & Drip tape & $75 \%$ \\
\hline
\end{tabular}




\section{Agricultural Research \& Technology: Open Access Journal}

\begin{tabular}{|c|c|c|c|c|c|c|}
\hline 148 & $5 / 16 / 2016$ & 23 & $\begin{array}{c}\text { Organic } \\
\text { Blackberry }\end{array}$ & 2.5 & Drip tape & $77 \%$ \\
\hline 149 & 06-09-2016 & 10 & $\begin{array}{c}\text { Organic } \\
\text { Blackberry }\end{array}$ & 1.7 & Drip tape & $57 \%$ \\
\hline 151 & $7 / 28 / 2016$ & 6.5 & Apple & 3.5 & Drip hose PC & $90 \%$ \\
\hline 152 & $8 / 19 / 2016$ & 15 & Apple & 3.8 & Micro-Sprinkler & $80 \%$ \\
\hline 153 & $9 / 16 / 2016$ & 40 & Strawberry & 3.8 & Drip tape & $83 \%$ \\
\hline 154 & $9 / 22 / 2016$ & 100 & Organic Romaine & 5.7 & Sprinklers & $76 \%$ \\
\hline 155 & $9 / 30 / 2016$ & 2.8 & Herbs & 0.83 & Drip tape & $92 \%$ \\
\hline 156 & $10 / 21 / 2016$ & 6.3 & $\begin{array}{c}\text { Organic } \\
\text { Strawberry }\end{array}$ & 0.9 & Drip tape & $67 \%$ \\
\hline 157 & 11-01-2016 & 12 & $\begin{array}{c}\text { Organic Wine } \\
\text { Grapes }\end{array}$ & 4.5 & Drip tape PC & $72 \%$ \\
\hline 158 & 02-01-2017 & 35 & Ornamentals & 5.25 & Drip tape & $75 \%$ \\
\hline 159 & $3 / 17 / 2017$ & 47.5 & Raspberry & 15 & Drip tape & $90 \%$ \\
\hline 160 & 04-11-2017 & 8 & $\begin{array}{c}\text { Organic } \\
\text { Strawberry }\end{array}$ & 1.8 & Drip tape & $91 \%$ \\
\hline 161 & $5 / 18 / 2017$ & 6 & $\begin{array}{c}\text { Organic } \\
\text { Strawberry }\end{array}$ & 1.4 & Drip tape & $88 \%$ \\
\hline 162 & $6 / 28 / 2017$ & 13.6 & $\begin{array}{c}\text { Organic } \\
\text { Strawberry }\end{array}$ & 3.5 & Drip tape & $75 \%$ \\
\hline \multicolumn{2}{|c|}{ Total 25 evaluations } & Total acres $=700.2$ & & $\begin{array}{c}\text { Evaluated acres }= \\
82.38\end{array}$ & & $\begin{array}{c}\text { Average DU = } \\
77.68 \%\end{array}$ \\
\hline
\end{tabular}

The evaluated irrigation systems included drip tape, drip hose, pressure compensating emitters, micro- sprinklers and overhead sprinklers irrigating various crops such as strawberry, vegetables, ornamentals, caneberries, apple and wine grapes (Table 1). On each ranch, only a fraction of the total ranch area was evaluated, usually one or two irrigation blocks. The evaluated irrigation blocks ranged in side from 0.6 acres to 5.7 acres and totaled 82 acres. Ranches ranged in size from 3 to 100 acres and the area of all ranches combined was 700 acres.

Table 2: Summary of recommendations resulting from system evaluation and their frequency.

\begin{tabular}{|c|c|}
\hline Recommendation & Frequency \\
\hline Buy pressure gages and install pressure measurement points & $48 \%$ \\
\hline Install pressure regulators & $44 \%$ \\
\hline Plugging issues, better flushing and fertigation management needed & $40 \%$ \\
\hline Fix leaks from driptapes causing runoff & $32 \%$ \\
\hline Install larger diameter lead hoses & $28 \%$ \\
\hline Install larger oval hose & $20 \%$ \\
\hline Adjust pressure regulators & $20 \%$ \\
\hline Valve choked or bleeding off water to decrease excessive pressure & $20 \%$ \\
\hline Change row or tape orientation & $16 \%$ \\
\hline Increase size of layflat serving block & $12 \%$ \\
\hline Perform filter maintenance & $12 \%$ \\
\hline Reduce pressure, overall too high & $12 \%$ \\
\hline Reduce irrigated area & $8 \%$ \\
\hline Mixed emitters or sprinklers & $8 \%$ \\
\hline Uneven drainage issues & $4 \%$ \\
\hline
\end{tabular}

Table 2 shows the recommendations resulting from the evaluations and the frequency of the recommendation. The most common recommendation was to install pressure checkpoint (Schrader valves) and to provide the irrigator with a handheld pressure gauge to check water pressure when operating the system. The second most common recommendation was to install pressure regulators to balance pressure between different blocks; this recommendation was very common in ranches with sloped fields. Plugged emitters were the third most common cause of poor DU, particularly in ranches where liquid organic 
fertilizer was injected in the system. Recommended practices to avoid plugging were: flushing tapes and manifolds after each fertigation and stopping the fertilizer injection at least 30 to 45 minutes before the end of the irrigation set to allow the fertilizer to be completely flushed from the drip lines. Fixing leaks and installing larger diameter oval hoses were the next most common recommendation for drip systems. In some ranches, pressure regulators were present, but the irrigator was not trained on how to adjust them or did not have a pressure gauge to measure the pressure. Thus, adjusting pressure regulators was also a common recommendation. Other recommendations included increasing the irrigated area instead of closing a valve to reduce pressure in the irrigation system, changing row orientation to lessen the slope of the rows, and improving maintenance of the filters.

Table 3: Results of statistical analysis of mean separations between treatments.

\begin{tabular}{|c|c|c|c|c|}
\hline Irrigation Method & $\begin{array}{c}\text { Number of } \\
\text { Evaluations (n) }\end{array}$ & Range in DU & Mean DU & Groups \\
\hline Drip hose PC & 2 & $72 \%$ to $90 \%$ & $83.40 \%$ & $\mathrm{a}$ \\
\hline Drip tape & 10 & $66 \%$ to $96 \%$ & $81 \%$ & $\mathrm{a}$ \\
\hline Organic drip & 8 & $57 \%$ to $91 \%$ & $76 \%$ & $\mathrm{a}$ \\
\hline Sprinklers & 4 & $68 \%$ to $80 \%$ & $75.50 \%$ & $\mathrm{a}$ \\
\hline
\end{tabular}

When grouped by irrigation method, drip tape showed the highest average DU (83\%) followed by drip hose with pressure compensating emitters (81\%), sprinklers (76\%) and the lowest was drip tape in organic production (75.5\%) (Figure 1). However, the differences in DU were not statistically significant (P-value 0.34 , Table 3). In one case pressure compensating systems did not yield a better DU than traditional driptape, since the system was run at a pressure below the pressure-compensating range of the emitters. Drip tape in organic ranches yielded poorer results than in conventional production, due to emitter plugging resulting from injecting organic liquid fertilizer, and because organic ranches are often located on marginal sloping land where differences in elevation affect the DU.

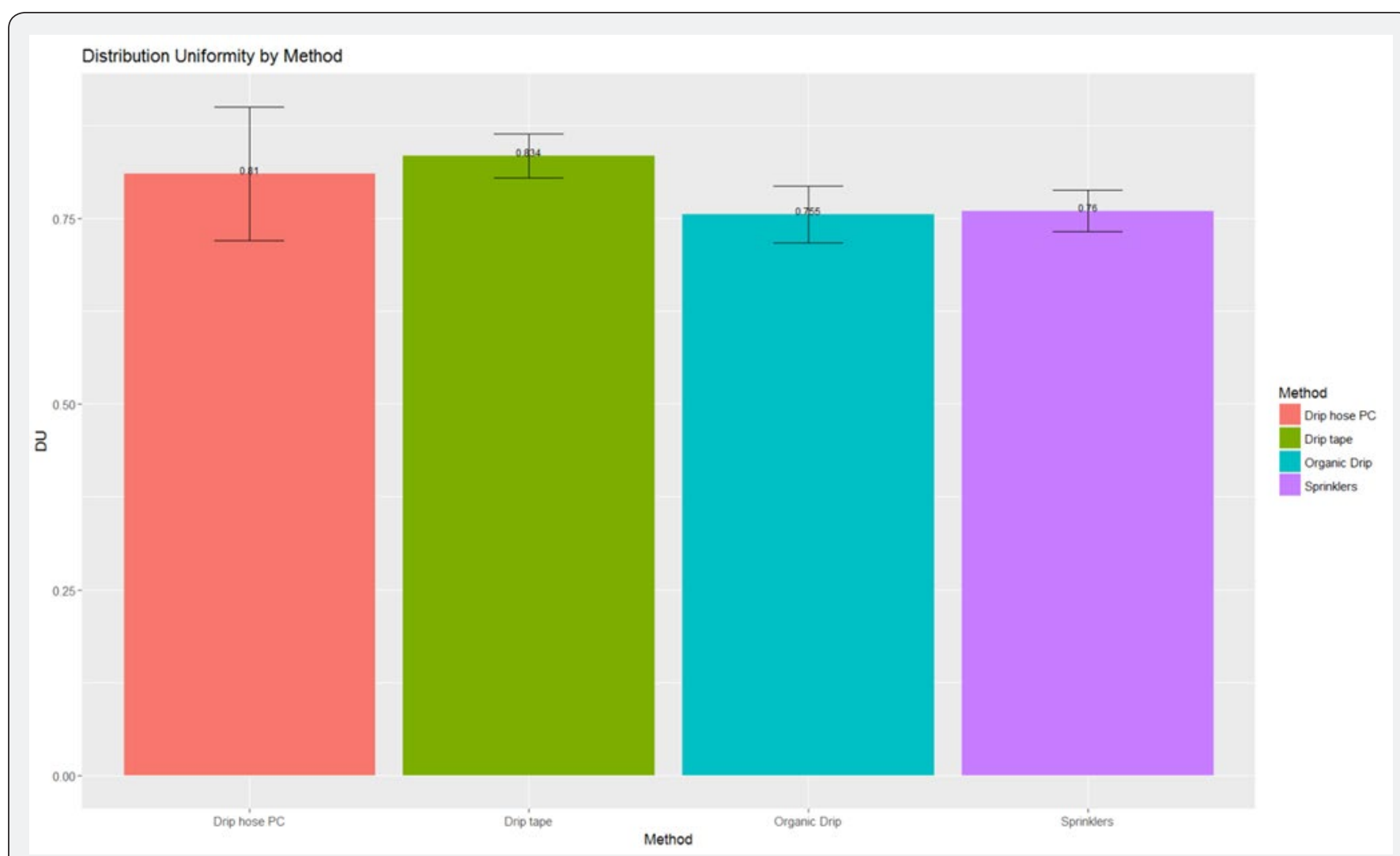

Figure 1: Results of the distribution uniformity evaluations grouped by method. The error bar represent the standard error of the mean. In the legend, "Drip Hose PC" refers to drip hose with pressure compensating emitters. 


\section{Agricultural Research \& Technology: Open Access Journal}

Table 4: Estimated potential water and cash savings for each evaluation performed Based on 250\$/AcFt for PVWMA augmentation fees and pumping costs.

\begin{tabular}{|c|c|c|c|c|c|c|c|c|}
\hline Ranch size & Crop & $\begin{array}{l}\text { Irrigation } \\
\text { method }\end{array}$ & $\begin{array}{l}\text { Distribution } \\
\text { Uniformity }\end{array}$ & Target DU & Avg ETc & \multicolumn{3}{|c|}{ Potential Savings } \\
\hline acres & & & & & inch/season & inch/season & AcFt/season & \$/season \\
\hline 34 & Strawberry & Drip tape & $96 \%$ & $96 \%$ & 26 & 0 & 0 & 0 \\
\hline 2.8 & Herbs & Drip tape & $92 \%$ & $92 \%$ & 24 & 0 & 0 & 0 \\
\hline 8 & $\begin{array}{c}\text { Organic } \\
\text { Strawberry }\end{array}$ & Drip tape & $91 \%$ & $91 \%$ & 26 & 0 & 0 & 0 \\
\hline 6.5 & Apple & Drip hose PC & $90 \%$ & $90 \%$ & 8 & 0 & 0 & 0 \\
\hline 47.5 & Raspberry & Drip tape & $90 \%$ & $90 \%$ & 20 & 0 & 0 & 0 \\
\hline 10.5 & Strawberry & Drip tape & $88 \%$ & $90 \%$ & 26 & 0.7 & 0.6 & 144 \\
\hline 6 & $\begin{array}{c}\text { Organic } \\
\text { Strawberry }\end{array}$ & Drip tape & $88 \%$ & $88 \%$ & 26 & 0 & 0 & 0 \\
\hline 62 & Strawberry & Drip tape & $87 \%$ & $90 \%$ & 26 & 1 & 5.1 & 1287 \\
\hline 50 & Strawberry & Drip tape & $84 \%$ & $90 \%$ & 26 & 2.1 & 8.6 & 2149 \\
\hline 40 & Strawberry & Drip tape & $83 \%$ & $85 \%$ & 26 & 0.7 & 2.5 & 614 \\
\hline 20 & Red Beets & Sprinklers & $80 \%$ & $80 \%$ & 18 & 0 & 0 & 0 \\
\hline 15 & Apple & $\begin{array}{l}\text { Micro- } \\
\text { Sprinkler }\end{array}$ & $80 \%$ & $85 \%$ & 8 & 0.6 & 0.7 & 184 \\
\hline 23 & $\begin{array}{c}\text { Organic } \\
\text { Strawberry }\end{array}$ & Drip tape & $77 \%$ & $90 \%$ & 26 & 4.9 & 9.3 & 2337 \\
\hline 100 & $\begin{array}{l}\text { Organic } \\
\text { Romaine }\end{array}$ & Sprinklers & $76 \%$ & $80 \%$ & 12 & 0.8 & 6.6 & 1645 \\
\hline 9 & $\begin{array}{c}\text { Organic } \\
\text { Blackberry }\end{array}$ & Drip hose & $75 \%$ & $90 \%$ & 20 & 4.4 & 3.3 & 833 \\
\hline 35 & Ornamentals & Drip tape & $75 \%$ & $85 \%$ & 26 & 4.1 & 11.9 & 2974 \\
\hline 13.6 & $\begin{array}{l}\text { Organic } \\
\text { Strawberry }\end{array}$ & Drip tape & $75 \%$ & $85 \%$ & 26 & 4.1 & 4.6 & 1156 \\
\hline 34 & $\begin{array}{c}\text { Organic } \\
\text { Blackberry }\end{array}$ & Drip hose & $74 \%$ & $90 \%$ & 20 & 4.8 & 13.6 & 3403 \\
\hline 40 & Strawberry & Drip tape & $73 \%$ & $85 \%$ & 26 & 5 & 16.8 & 4190 \\
\hline 12 & $\begin{array}{c}\text { Organic Wine } \\
\text { Grapes }\end{array}$ & Drip hose PC & $72 \%$ & $90 \%$ & 8 & 2.2 & 2.2 & 556 \\
\hline 20 & $\begin{array}{c}\text { Potted } \\
\text { ornamentals }\end{array}$ & Sprinklers & $68 \%$ & $80 \%$ & 35 & 7.7 & 12.9 & 3217 \\
\hline 6.3 & $\begin{array}{l}\text { Organic } \\
\text { Strawberry }\end{array}$ & Drip tape & $67 \%$ & $80 \%$ & 26 & 6.3 & 3.3 & 828 \\
\hline 45 & Strawberry & Drip tape & $66 \%$ & $85 \%$ & 26 & 8.8 & 33 & 8255 \\
\hline 10 & $\begin{array}{c}\text { Organic } \\
\text { Strawberry }\end{array}$ & Drip tape & $57 \%$ & $80 \%$ & 26 & 13.1 & 10.9 & 2732 \\
\hline 50 & $\begin{array}{l}\text { Raspberry \& } \\
\text { Blackberry }\end{array}$ & $\begin{array}{l}\text { Drip tape/ } \\
\text { hose }\end{array}$ & $38 \%$ & $90 \%$ & 23 & 35 & 2.9 & 729 \\
\hline $\begin{array}{l}\text { Total acres } \\
\quad=700.2\end{array}$ & & & $\begin{array}{c}\text { Average DU = } \\
77.68 \%\end{array}$ & $\begin{array}{l}\text { Avg TargetDU } \\
=87 \%\end{array}$ & & & $\begin{array}{l}\text { Tot Savings } \\
=149 \mathrm{AcFt}\end{array}$ & \\
\hline
\end{tabular}

Table 4 summarizes the potential savings estimated for each ranch based on the measured DU, the target DU considered achievable for the ranch conditions, and the estimated average

of volumes of water in Acre-feet (Ac-ft)/season were calculated for each ranch assuming that the grower would implement recommendations across their whole ranch, improving the DU seasonal evapotranspiration of the crop. Potential savings in terms

from the observed to the target value. Monetary savings were 
also calculated based on PVWMA augmentation fees and average pumping costs. In some cases, the potential cash savings exceed the costs of the equipment needed to improve the DU, which would also result in indirect revenue for the farming operation due to less nitrogen leaching, increased yields, and regulatory relief. However, the total estimated potential savings for all farms evaluated was $149 \mathrm{Ac}$-ft per season, which is a relatively modest savings, compared to PVWMA's basin-wide conservation target of 5000 Ac-ft by 2035.

In some systems evaluated, the measured application rate deviated substantially from the design application rate (Table
5), with the measured application rate ranging from 63\% higher, to $32 \%$ lower than the designed application rate. This deviation was observed regardless of the measured DU and was common even in fields with very high distribution uniformity. This occurred usually because the operating pressure was higher or lower than recommended by the drip tape manufacturer. Knowledge of the actual application rate is crucial to correctly schedule irrigation events. For example the first ranch in Table 5, although presenting a DU of $96 \%$, would be under-irrigating by $15 \%$, whereas the third ranch, with a DU of $91 \%$ would be underirrigating by $19 \%$. These results suggest that even very efficient system can be hindered by improper management.

Table 5: The design application rate and the measured application rate for the irrigation systems evaluated.

\begin{tabular}{|c|c|c|c|c|c|}
\hline Crop & Irrigation Method & $\begin{array}{l}\text { Distribution } \\
\text { Uniformity }\end{array}$ & $\begin{array}{c}\text { Design Application } \\
\text { Rate }\end{array}$ & Measured App Rate & Difference \\
\hline & & & in $/ \mathrm{hr}$ & in $/ \mathrm{hr}$ & $\%$ \\
\hline Strawberry & Drip tape & $96 \%$ & 0.222 & 0.19 & $-14 \%$ \\
\hline Herbs & Drip tape & $92 \%$ & 0.359 & 0.29 & $-19 \%$ \\
\hline Organic Strawberry & Drip tape & $91 \%$ & 0.193 & 0.23 & $19 \%$ \\
\hline Apple & Drip hose PC & $90 \%$ & 0.025 & 0.027 & $6 \%$ \\
\hline Raspberry & Drip tape & $90 \%$ & 0.076 & 0.08 & $6 \%$ \\
\hline Strawberry & Drip tape & $88 \%$ & 0.298 & 0.35 & $18 \%$ \\
\hline Organic Strawberry & Drip tape & $88 \%$ & 0.303 & 0.31 & $2 \%$ \\
\hline Strawberry & Drip tape & $87 \%$ & 0.222 & 0.18 & $-19 \%$ \\
\hline Strawberry & Drip tape & $84 \%$ & 0.222 & 0.15 & $-32 \%$ \\
\hline Strawberry & Drip tape & $83 \%$ & 0.151 & 0.174 & $15 \%$ \\
\hline Red Beets & Drip tape & $80 \%$ & 0.287 & 0.31 & $8 \%$ \\
\hline Apple & Drip tape & $80 \%$ & 0.069 & 0.094 & $37 \%$ \\
\hline Organic Strawberry & Drip tape & $77 \%$ & 0.193 & 0.21 & $9 \%$ \\
\hline
\end{tabular}




\begin{tabular}{|c|c|c|c|c|c|}
\hline Organic Romaine & Drip tape & $76 \%$ & 0.239 & 0.23 & $-4 \%$ \\
\hline Organic Blackberry & Drip tape & $75 \%$ & 0.106 & 0.09 & $-15 \%$ \\
\hline Ornamentals & Drip tape & $75 \%$ & 0.176 & 0.21 & $19 \%$ \\
\hline Organic Strawberry & Drip tape & $75 \%$ & 0.303 & 0.27 & $-11 \%$ \\
\hline Organic Blackberry & Drip tape & $74 \%$ & 0.212 & 0.16 & $-24 \%$ \\
\hline Strawberry & Drip tape & $73 \%$ & 0.222 & 0.28 & $26 \%$ \\
\hline Organic Wine Grapes & Drip tape & $72 \%$ & 0.048 & 0.044 & $-10 \%$ \\
\hline Potted ornamentals & Drip tape & $68 \%$ & 0.509 & 0.83 & $63 \%$ \\
\hline Organic Strawberry & Drip tape & $67 \%$ & 0.289 & 0.2 & $-31 \%$ \\
\hline Strawberry & Drip tape & $66 \%$ & 0.151 & 0.22 & $46 \%$ \\
\hline Organic Strawberry & Drip tape & $57 \%$ & 0.289 & 0.23 & $-20 \%$ \\
\hline $\begin{array}{l}\text { Raspberry \& } \\
\text { Blackberry }\end{array}$ & Drip tape & $38 \%$ & 0.063 & 0.08 & $28 \%$ \\
\hline
\end{tabular}

A negative correlation was found between the slope of the ranch and the DU measured for drip systems and a positive correlation for sprinkler systems (Figure 2). The linear regressions were not statistically significant when the data was grouped by method (Drip and Sprinkler in Table 5), due to the significant scatter in DU for ranches without significant

slope. When only drip system at ranches with appreciable slope (higher than 1.5\%) was considered, the linear regression was significant (Table 6 \& Figure 3). This correlation appears to be caused by the high variability of pressure caused by differences in elevation and highlights the importance of pressure regulators and adequate row orientation on sloped fields.

Table 6: Linear regression analysis of the relationship between distribution uniformity and ranch slope.

\begin{tabular}{|c|c|c|c|c|c|}
\hline Irrigation Method & $\begin{array}{c}\text { Number of } \\
\text { Evaluations (n) }\end{array}$ & Range in DU & $\begin{array}{c}\text { Range in Ranch } \\
\text { Slope }\end{array}$ & Regression Slope & P-value \\
\hline Drip & 21 & $38 \%$ to $96 \%$ & $0.5 \%$ to $15 \%$ & -0.99 & 0.178 \\
\hline \begin{tabular}{c} 
Sprinkler \\
\hline
\end{tabular} & 4 & $68 \%$ to $80 \%$ & $0.5 \%$ to $10 \%$ & 0.225 \\
\hline $\begin{array}{c}\text { Drip with ranch slope } \\
>1.5 \%\end{array}$ & 10 & $57 \%$ to $92 \%$ & $1.7 \%$ to $15 \%$ & -2.2 & $0.00184^{* *}$ \\
\hline
\end{tabular}




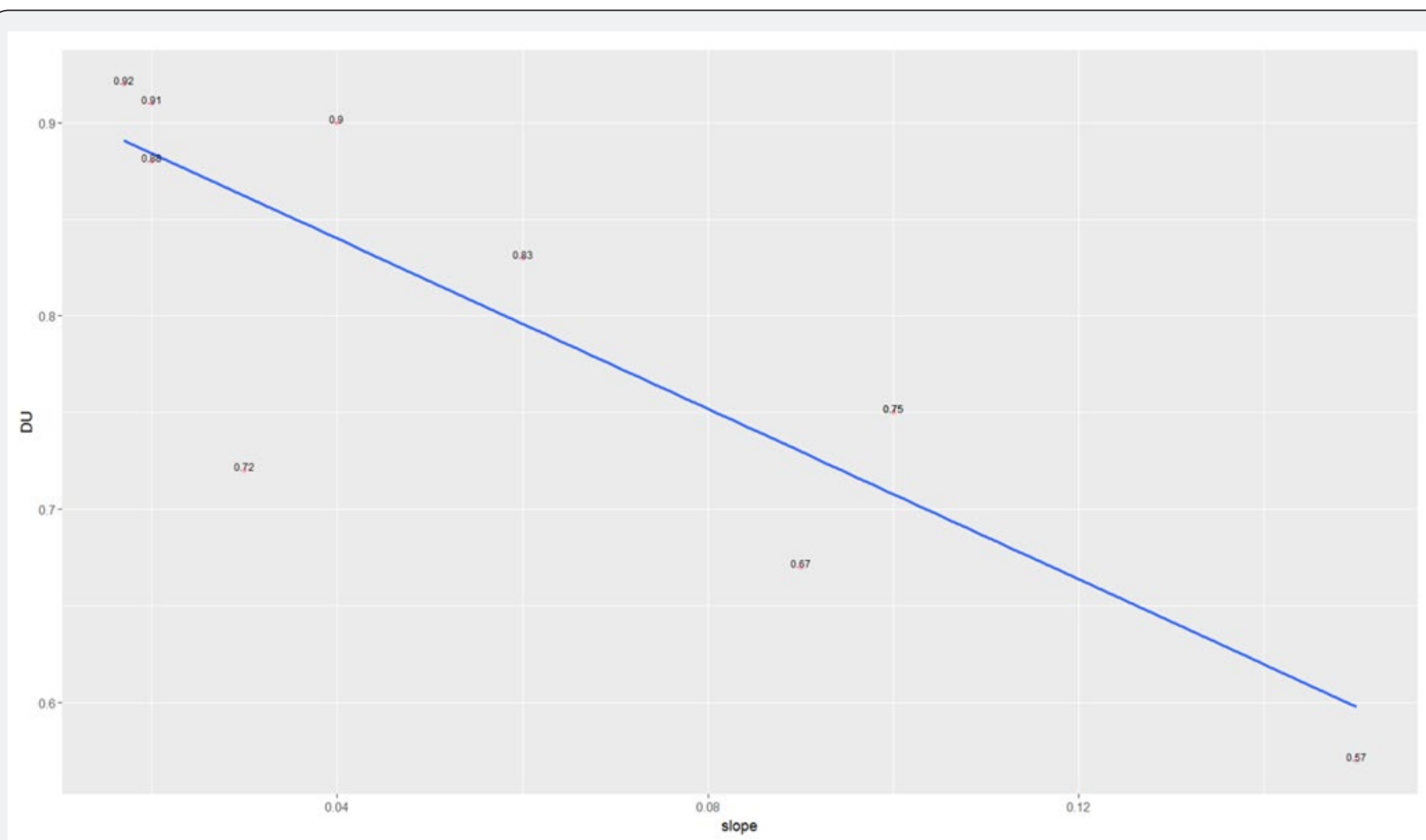

Figure 2: Linear regressions between the measured distribution uniformity (DU) and the ranch slope for drip (pink) and sprinkler systems (blue). Symbol colors differentiates between drip in conventional production, drip in organic production and sprinklers.

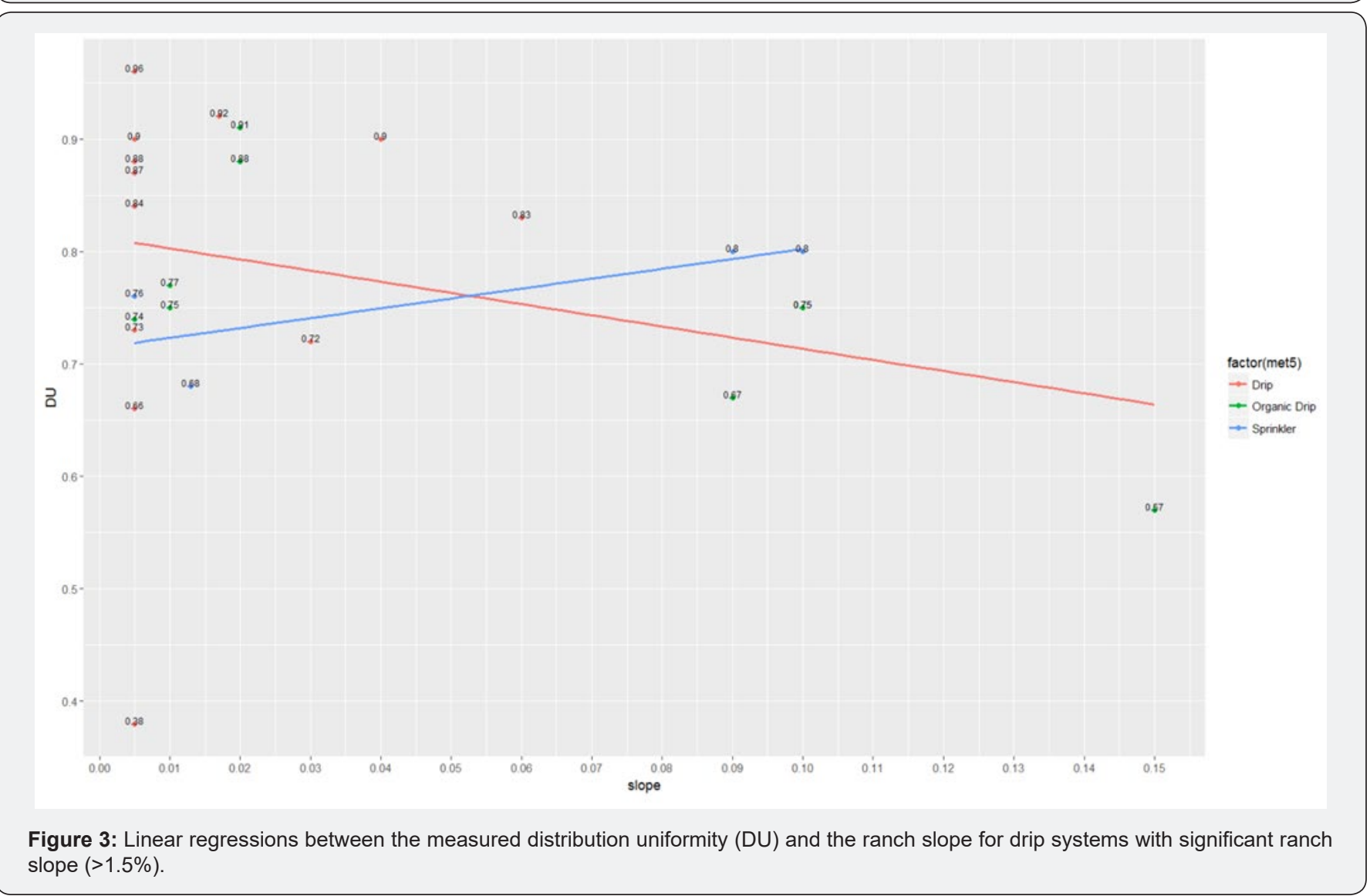


This work is licensed under Creative Commons Attribution 4.0 License DOI: 10.19080/ARTOAJ.2018.14.555925
Your next submission with Juniper Publishers will reach you the below assets

- Quality Editorial service

- Swift Peer Review

- Reprints availability

- E-prints Service

- Manuscript Podcast for convenient understanding

- Global attainment for your research

- Manuscript accessibility in different formats ( Pdf, E-pub, Full Text, Audio)

- Unceasing customer service

Track the below URL for one-step submission https://juniperpublishers.com/online-submission.php 